\title{
Suggested Model for Heat Transfer Calculation During Fluid Flow in Single Phase Inside Pipes (II)
}

\author{
Yanán Camaraza-Medina $^{1 *}$, Ken Mortensen-Carlson ${ }^{2}$, Pratijay Guha ${ }^{3}$, Ángel M. Rubio-Gonzales ${ }^{1}$, Oscar M. Cruz-Fonticiella ${ }^{1}$ \\ Osvaldo F. García-Morales ${ }^{4}$ \\ ${ }^{1}$ Center of Energy Studies and Environmental Technology, Universidad Central "Marta Abreu" de Las Villas 54440, Cuba \\ ${ }^{2}$ Department of Chemical Engineering, University of California, Santa Bárbara CA 93106, USA \\ ${ }^{3}$ Department of Mechanical Engineering, Birla Institute of Technology and Sciences, Pilani Hyderabad 333031, India \\ ${ }^{4}$ Technical Sciences Faculty, Universidad de Matanzas, Matanzas 44440, Cuba
}

Corresponding Author Email: ycamaraza1980@yahoo.com

https://doi.org/10.18280/ijht.370131

Received: 11 December 2018

Accepted: 5 March 2019

\section{Keywords:}

single phase, model, heat transfer coefficient, average deviation

\begin{abstract}
In this paper, is presented a mathematical deduction of a new improved model for heat transfer calculations during fluid flow in single-phase inside tubes. The proposal model was verified by comparison with available experimental data of 35 different fluids, including water, air, gases and organic substances. The proposal model is valid for a range of Reynolds number for single-phase from $2.4 \cdot 10^{3}$ to $8.2 \cdot 10^{6}$, Prandtl number for single-phase from 0.65 to 4.71 . $10^{4}$, dimensionless length in the interval $2 \leq l / d \leq 450$ and values of Petukhov's correction in the interval $0.006 \leq \mu_{F} / \mu_{P} \leq 177$. In 3096 data analyzed, for $R e<1 \cdot 10^{4}$, the mean deviation found was $13.91 \%$ in the $80.32 \%$ of the experimental data, while for $1 \cdot 10^{4} \leq$ $R e$, the mean deviation found was $13.96 \%$ in $80.94 \%$ of experimental data.
\end{abstract}

\section{INTRODUCTION}

Currently, heat transfer calculations for turbulent fluid flow within straight conduits in single-phase media are made by the Dittus-Boelter equation, or by the improved version of SiederTate [1]. This procedure is a requirement for the evaluation of industrial facilities or production equipment. A drawback of these equations is their high dispersion value, reaching compute errors close to $\pm 40 \%$.

At the Moscow Energy Institute, Petukhov and his collaborators constructed a model based on experimental quantity adjustments, using the Prandtl analogy as an adjustment function [2]. This equation gives results with a lower margin of error, and allows us to estimate the mean error by the dimensionless number of Prandtl.

$$
\begin{array}{ll}
\text { if } \operatorname{Pr} \leq 200 & \text { Error }<5 \% \\
\text { if } \operatorname{Pr} \geq 200 & \text { Error } \leq 10 \%
\end{array}
$$

Although the application of the Petukhov's Equation is more laborious, the results obtained have a minor dispersion, therefore, a smaller safety margin in the design calculations.

A major drawback is its applicability range, because this is only valid for a fully developed turbulent flow regime, 1 . $10^{4}<R e$, and is not valid for the flow that operate in the transition zone $2.3 \cdot 10^{3}<R e<1 \cdot 10^{4}$. This problem was later solved by Gnielinsky [3-4], who modified the Petukhov's Equation, adjusting it to experimental data that do take into account the transition flow zone.

In the literature can be found an important group of works that facilitate the calculation of heat transfer inside of straight tubes with turbulent flow, this is mainly associated with the changing nature of the turbulent flow, which hinders the development of analytical expressions. This element makes it necessary to resort to the experimentation and subsequent adjustment of experimental quantities through the theory of dimensional analysis.

\section{METHODS AND VALIDATION}

\subsection{Analogy between heat transfer and momentum in single-phase fluid flow inside pipes}

The Darcy friction factor $f$ allows determining the heat transfer coefficient $\alpha$, by analogy between heat transfer and momentum. The shear stress $\tau$ in the turbulent boundary layer is composed of two terms [5]:

$$
\tau=\tau_{V i s c}+\tau_{T u r b}=\mu \frac{d V}{d x}-\rho V_{X}^{*} V_{Y}^{*}
$$

In Equation (1) $\tau_{\text {Turb }}$ is the Reynolds stress; $V_{X}^{*}$ is the fluctuation of the instantaneous velocity $V_{X}^{M}$ in the coordinate axis $x$; $V_{Y}^{*}$ is the fluctuation of the instantaneous velocity $V_{Y}^{M}$ in the coordinate axis $y$.

The instantaneous velocity $V_{X}^{M}$ and $V_{Y}^{M}$ are determined as:

$V_{X}^{M}=V_{M}^{X} \pm V_{X}^{*}=V_{M}^{X} \pm V_{\text {agit }}^{X}$

$V_{Y}^{M}=V_{M}^{Y} \pm V_{Y}^{*}=V_{M}^{Y} \pm V_{a g i t}^{Y}$

For turbulent heat flow, it can be considered that the total heat flow $\mathrm{q}^{*}$ is composed of a sum that includes the conductive component $\mathrm{q}_{\text {cond }}$ and the turbulent component $\mathrm{q}_{\text {turb }}$, then: 
$q^{*}=q_{\text {cond }}+q_{\text {turb }}=-\lambda \frac{d T}{d x}+\rho C p V_{Y}^{*} T_{F}^{*}$

In Equation (3) there are three temperature references, which are:

$T_{I}=T_{F} \pm T_{F}^{*} \quad$ is the instantaneous temperature

$T_{F}=T_{\infty} \quad$ is the mean temperature of the fluid

$T_{F}^{*} \quad$ is the temperature due to the fluctuation

Terms $V_{X}^{*}$ and $V_{Y}^{*}$ are obtained from their physical meaning from the Prandtl mixing number, which suggests that the fluctuation of velocity $V_{X}^{*}$ is related with $d V / d x$ as:

$V_{X}^{*} \approx L_{M} d V / d x$

In Equation (6), $L_{M}$ is the mixture length of the thickness film $\delta_{2}$ of the momentum in boundary layer. Similarly, transverse fluctuation $V_{Y}^{*}$ is admitted to be of the same order of magnitude $V_{X}^{*}$ but opposite in sign, [6]:

$V_{Y}^{*} \approx-L_{M} d V / d x$

Combining the Equations (6) and (6.a):

$V_{X}^{*} V_{Y}^{*} \approx-\left(L_{M} d V / d x\right)^{2}$

Equation (7) can be transformed to:

$V_{X}^{*} V_{Y}^{*} \approx \varepsilon_{M} d V / d x$

In Equation (8) $\varepsilon_{M}$ is the momentum turbulent diffusivity, then:

$\varepsilon_{M} \approx L_{M}^{2} d V / d x$

To find the relationship of the term $V_{Y}^{*} T_{F}^{*}$, with the mean local temperature gradient, a similar method is applied, in the form [6].

$T_{F}^{*} \approx-L_{C} d T / d x$

$V_{Y}^{*}=L_{C} d V / d x$

In the expression (11) $L_{C}$ is the mixture length of the energy in the thickness $\delta_{3}$ of the thermal boundary layer, then:

$V_{Y}^{*} T_{F}^{*}=-L_{C}^{2} \frac{d V}{d x} \frac{d T}{d x}=-\varepsilon_{C} \frac{d T}{d x}$

In the Equation (12), the term $\varepsilon_{C}=-L_{C}^{2} d V / d x$ is the heat turbulent diffusivity. Substituting Equation (8) into Equation (1):

$\tau=\tau_{V i s c}+\tau_{\text {Turb }}=\mu d V / d x-\rho \varepsilon_{M} d V / d x$

Dividing by the density $\rho$ to both members of the Equation (13) and taken the derivative $d V / d x$ as a common factor [78], then: $\frac{\tau}{\rho}=\tau_{\text {Visc }}+\tau_{\text {Turb }}=\left(\frac{\mu}{\rho}+\varepsilon_{M}\right) \frac{d V}{d x}=\left(v+\varepsilon_{M}\right) \frac{d V}{d x}$

Substituting Equation (12) into Equation (4):

$q^{*}=q_{\text {cond }}+q_{\text {turb }}=-\lambda \frac{d T}{d x}-\rho C p \varepsilon_{C} \frac{d T}{d x}$

If in Equation (15) the derivative $d T / d x$ is taken as a common factor, then

$q^{*}=q_{\text {cond }}+q_{\text {turb }}=-\left(\lambda+\rho C p \varepsilon_{C}\right) d T / d x$

In Equation (16), both members are divided by the product of the density and specific heat at constant pressure $\rho C p$.

$\frac{q^{*}}{\rho C p}=-\left(\frac{\lambda}{\rho C p}+\varepsilon_{C}\right) \frac{d T}{d x}=-\left(a+\varepsilon_{C}\right) \frac{d T}{d x}$

Dividing Equation (17) by the Equation (14) is obtained the basic relationships for the fluid flow inside of tubes [6-9]:

$\frac{\tau}{q^{*}}=-\frac{v+\varepsilon_{M}}{C p\left(a+\varepsilon_{C}\right)} \frac{d V}{d T}$

In Equation (18), the kinematic viscosity $v$ and the thermal diffusivity $a$ are properties of the fluid, while $\varepsilon_{C}$ and $\varepsilon_{M}$ are properties of the flow.

\subsection{Development of one linear model for convective heat transfer calculation in single-phase inside pipes}

Development of the new model for to calculate the convective heat transfer in single-phase inside pipes is a complex task. Initially is taken the criterion established by Prandtl, which considers that the flow is divided into two zones, a viscous zone and a turbulent zone. In his analysis Prandtl makes the additional assumptions that in the turbulent zone the molecular diffusivities of momentum $v$ and of heat $a$, are negligible in comparison with the turbulent diffusivities, $v \gg \varepsilon_{M}$ and $a \gg \varepsilon_{C}$, so they do not intervene in the process. It would be very useful for such a purpose to assume that the relationship between molecular diffusivities $a$ and $v$ is equal to the relationship between diffusivities $\varepsilon_{C}$ and $\varepsilon_{M}$.

Since the dimensionless Prandtl number is a relation between diffusivities, then the previous assumption is fulfilled [10].

$\operatorname{Pr}=v / a=\varepsilon_{M} / \varepsilon_{C}$

Clearing $v$ and $\varepsilon_{M}$ in the Equation (19):

$v=a P r$

$\varepsilon_{M}=\varepsilon_{C} P r$

Substituting Equations (20) and (21) into Equation (18):

$\frac{\tau}{q^{*}}=-\frac{a \operatorname{Pr}+\varepsilon_{C} \operatorname{Pr}}{C p\left(a+\varepsilon_{C}\right)} \frac{d V}{d T}$ 
If the Prandtl number $\mathrm{Pr}$ is taken as a common factor in Equation (22), it is reduced to [11]:

$\frac{\tau}{q^{*}}=\frac{\tau_{0}}{q_{0}^{*}}=-\frac{\left(a+\varepsilon_{C}\right) \operatorname{Pr}}{\left(a+\varepsilon_{C}\right) C p} \frac{d V}{d T}=-\frac{\operatorname{Pr}}{C p} \frac{d V}{d T}$

Separating variables in (23) and integrating

$\int_{0}^{V_{M}} d V=-\frac{C p \tau_{0}}{\operatorname{Pr} q_{0}^{*}} \int_{T_{P}}^{T_{F}} d T$

Resolving the integrals present in Equation (24) and grouping conveniently:

$V_{M}=\frac{C p \tau_{0}}{\operatorname{Pr} q_{0}^{*}}\left(T_{P}-T_{F}\right)$

In Equation (25) the terms $\tau_{0}$ and $q_{0}^{*}$ are taken on the surface. It is known from the fluid mechanics courses that [10]:

$\pi d L \tau_{0}=\Delta p \pi d^{2} / 4$

Clearing $\Delta P$ in Equation (26)

$\Delta P=4 L \tau_{0} / d$

The Darcy Equation for surface is:

$\Delta P=\frac{f L V_{M}^{2} \rho}{2 d}$

Equaling the Equations (28) and (27)

$4 L \tau_{0} / d=f \frac{L V_{M}^{2} \rho}{2 d}$

The shear stress $\tau_{0}$ on the surface is given in the left term of the Equation (29), therefore, clearing it, can be obtaining the expression that allows determining the shear stress $\tau_{0}$ on the surface [12].

$\tau_{0}=\frac{f V_{M}^{2} \rho}{2}$

The mean drag coefficient is taken as a quarter of the Darcy friction factor

$C_{W}=f / 4$

Then, substituting the Equation (31) into Equation (30)

$\tau_{0}=\frac{C_{W} \rho V_{M}^{2}}{2}$

The quantity of heat transferred is obtained with the Newton's law of cooling [11-13].

$q_{0}^{*}=\alpha\left(T_{P}-T_{F}\right)$

Substituting the Equations (33) and (32) into Equation (25):
$V_{M}=\frac{C p f \rho V_{M}^{2}}{8 \operatorname{Pr} \alpha\left(T_{P}-T_{F}\right)}\left(T_{P}-T_{F}\right)$

Equation (34) is transformed to:

$V_{M}=\frac{\operatorname{Cpf} \rho V_{M}^{2}}{8 \operatorname{Pr} \alpha}$

Clearing the mean heat transfer coefficient $\alpha$ in Equation (35):

$\alpha=\frac{C p f \rho V_{M}}{8 \operatorname{Pr}}$

Equation (36) contains all the physical properties necessary to form the Stanton dimensionless group.

$S t=\frac{N u}{\operatorname{Re} \operatorname{Pr}}=\frac{\alpha}{\rho C p V_{M}}$

Substituting Equation (37) into Equation (36)

$\frac{\alpha}{C p \rho V_{M}}=\frac{N u}{\operatorname{RePr}}=S t=\frac{f}{8 \operatorname{Pr}}$

From the Equation (31), Equation (38) is transformed to:

$\frac{\alpha}{C p \rho V_{M}}=\frac{N u}{\operatorname{RePr}}=S t=\frac{C_{W}}{2 \operatorname{Pr}}$

Solving the average drag coefficient $C_{W}$ in the Equation (39)

$C_{W}=2 S t \operatorname{Pr}$

Equation (39.a) is a good approximation to the model given by Pohlhausen [12-13].

$C_{W}=2 S t \operatorname{Pr}^{2 / 3}$

Equation (40) agrees very well with the experimental values for $\operatorname{Pr} \approx 1$. The friction factor is obtained with the Equation given by Eckert [12-14].

$f=0.184 \mathrm{Re}^{-0.2}$

Equation (41) is valid for:

$10^{4}<\operatorname{Re}<10^{5} \quad ; \quad L / d=0.623 \sqrt[4]{\operatorname{Re}}$

In Equation (42) $L$ is the initial section of hydrodynamic compensation (necessary distance so that in turbulent flow the Darcy's friction factor $f$ becomes constant). Substituting the Equations (41) into Equation (40):

$N u=S t \operatorname{Re} \operatorname{Pr}=\frac{f}{8 \cdot \sqrt[3]{\operatorname{Pr}}} \operatorname{Re} \operatorname{Pr}^{2 / 3}=$

$=\frac{0,184}{8} \operatorname{Re}^{0.8} \operatorname{Pr}^{1 / 3}=0,023 \operatorname{Re}^{0.8} \operatorname{Pr}^{1 / 3}$ 
Equation (43) is valid for:

$10^{4}<\operatorname{Re}<10^{5} \quad ; \quad \frac{L}{d}>60 \quad ; \quad 0.5<\operatorname{Pr}<100$

Equation (43) was later modified by Dittus-Boelter [15], where, the exponent $1 / 3$ from the Prandtl number was substituted by the constant $n$, which takes values of 0.3 and 0.4 for cooling and heating respectively. This action broadens the area of applicability of Equation (43) to [16-18]:

$$
10^{4}<\operatorname{Re} \quad ; \quad \frac{L}{d}>60 \quad ; \quad 0.5<\operatorname{Pr}<160
$$

\subsection{Deduction and development of the proposal model}

If it is considered that $v / a=1$, then $\varepsilon_{M}=\varepsilon_{C}$ and the Equation (23) is transformed to:

$$
\frac{\tau}{q^{*}}=\frac{\tau_{0}}{q_{0}^{*}}=-\frac{\varepsilon_{M}}{\varepsilon_{C}} \frac{d V}{C p d T}=-\frac{d V}{C p d T}
$$

In the viscous sublayer it is satisfied that $v \gg \varepsilon_{M}$ and $a \gg$ $\varepsilon_{C}$, then, transforming the Equation (46):

$\frac{\tau}{q^{*}}=\frac{\tau_{0}}{q_{0}^{*}}=-\frac{v}{a} \frac{d V}{C p d T}=-\frac{\operatorname{Pr}}{C p} \frac{d V}{d T}$

Separating variables in Equation (47), assuming that the profile of temperature distribution on the turbulent boundary layer is approximately a parabolic-exponential curve, we obtain:

$d T=-\operatorname{Pr}^{2 / 3} \frac{q_{0}^{*}}{C p \tau_{0}} d V$

Integrating in the Equation (48), the left member between the wall temperatures $T_{P}$ and the temperature on the edge of the viscous boundary layer $T_{1}$, the member on the right is integrated in the interval from zero until the edge velocity in the tube wall.

$\int_{T_{P}}^{T_{1}} d T=\int_{0}^{V_{1}}-\operatorname{Pr}^{2 / 3} \frac{q_{0}^{*}}{C p \tau_{0}} d V$

Solving the integrals present in Equation (49):

$T_{P}-T_{1}=-\operatorname{Pr}^{2 / 3} \frac{q_{0}^{*}}{C p \tau_{0}} V_{1}$

Separating variables in the Equation (46):

$d T=-\frac{q_{0}^{*}}{C p \tau_{0}} d V$

Integrating the Equation (51), in the left member, between the temperature on the edge of the viscous boundary layer and the average temperature of the fluid flow. The right member is integrated in the interval between the velocity on the edge of the viscous boundary layer and the mean velocity of the fluid stream, then:

$\int_{T_{1}}^{T_{F}} d T=\int_{V_{1}}^{V_{M}}-P \frac{q_{0}^{*}}{C p \tau_{0}} d V$

Resolving the integrals present in Equation (52)

$T_{1}-T_{F}=\frac{q_{0}^{*}}{C p \tau_{0}}\left(V_{M}-V_{1}\right)$

Adding the Equations (53) and (50), we obtain [19]:

$T_{P}-T_{1}+T_{1}-T_{F}=-\operatorname{Pr}^{2 / 3} \frac{q_{0}^{*}}{C p \tau_{0}} V_{1}+$

$+\left(q_{0}^{*} / C p \tau_{0}\right) \cdot\left(V_{M}-V_{1}\right)$

Grouping terms in Equation (54) is up to:

$T_{P}-T_{F}=\frac{q_{0}^{*} V_{M}}{C p \tau_{0}}\left[1+\frac{V_{1}}{V_{M}}\left(\operatorname{Pr}^{2 / 3}-1\right)\right]$

Substituting Equations (30) and (33) into Equation (55)

$T_{P}-T_{F}=\frac{8 \alpha\left(T_{P}-T_{F}\right) V_{M}}{C p f \rho V_{M}^{2}}\left[1+\frac{V_{1}}{V_{M}}\left(\operatorname{Pr}^{2 / 3}-1\right)\right]$

Clearing the mean heat transfer coefficient $\alpha$ in the Equation (56) and grouping conveniently is finally obtained [20-21]:

$\alpha=\frac{f}{8} \frac{\rho C p V_{M}}{\left[1+\frac{V_{1}}{V_{M}}\left(\operatorname{Pr}^{2 / 3}-1\right)\right]}$

Substituting Equation (37) into Equation (57)

$\frac{\alpha}{C p \rho V_{M}}=S t=\frac{N u}{\operatorname{Re} \operatorname{Pr}}=\frac{f}{8\left[1+\frac{V_{1}}{V_{M}}\left(\operatorname{Pr}^{2 / 3}-1\right)\right]}$

The velocity on the edge of the viscous boundary layer $V_{I}$ is determined with the aid of the law of velocities distribution for turbulent flows, applying the Schlichting Equation [22]:

$\frac{\tau_{0}}{\rho}=\left(\frac{V_{1}}{12.7}\right)^{2}=\frac{f V_{M}^{2}}{8}$

Clearing the velocities of the left member in Equation (59), we obtain that:

$\frac{V_{1}}{V_{M}}=12.7 \sqrt{\frac{f}{8}}$

Substituting Equation (60) into Equation (58) gives the final Stanton number. 
$\frac{\alpha}{C p \rho V_{M}}=S t=\frac{N u}{\operatorname{Re} \operatorname{Pr}}=\frac{\frac{f}{8}}{1+12.7 \sqrt{\frac{f}{8}}\left(\operatorname{Pr}^{2 / 3}-1\right)}$

or:

$$
N u=\frac{f \operatorname{Re} \operatorname{Pr}}{8+\sqrt{1290,3 f} \cdot\left(\operatorname{Pr}^{2 / 3}-1\right)}
$$

Equation (62) is the starting point for the development of a new model that allows to obtain the coefficient of heat transfer in single phase. This includes a smaller margin of error with respect to the existing models and with a greater range of applicability.

To consider the effect of the variation of the fluid physical properties along of the tube, the Equation (62) is affected by the factor of correction given by Petukhov [16-18]:

$$
N u=\frac{f \operatorname{Re} \operatorname{Pr}}{8+\sqrt{1290.3 f} \cdot\left(\operatorname{Pr}^{2 / 3}-1\right)} \cdot\left(\frac{\mu_{F}}{\mu_{P}}\right)^{N}
$$

In Equation (63), the coefficient $N$ take values 0.25 y 0.11 for cooling and heating of the fluid respectively.

When an initial section of hydrodynamic compensation is not available, it is necessary to include this correction, transforming Equation (63)

$$
=\frac{N u=\frac{f R e P r}{8+\sqrt{1290.3 f} \cdot\left(\operatorname{Pr}^{\frac{2}{3}}-1\right)\left(1+\left(\frac{d}{l}\right)^{\frac{2}{3}}\right)\left(\frac{\mu_{F}}{\mu_{P}}\right)^{N}}}{}
$$

The friction factor is obtained with the application of the Equation of Filonenko [15-16]:

$f=(1.82 \log (\operatorname{Re})-1.64)^{-2}$

Equation (65) is conveniently transformed to:

$f^{2}=\left[\log (R e)^{1.82}-1.64\right]^{-1}$

Applying logarithm properties in the Equation (66), taking one constant equal to 3.25 as a common factor:

$f^{2}=\left(3.25 \cdot\left(\log (\operatorname{Re})^{1.82 / 3.25}-1.64 / 3.25\right)\right)^{-1}$

Then:

$f^{2}=\left(3.25 \cdot\left(\log (\operatorname{Re})^{0.56}-0.505\right)\right)^{-1}$

Simplifying the Equation (68).

$f^{2}=\left[3.25 \cdot \log \left(\frac{R e^{0.56}}{3.196}\right)\right]^{-1}$

or

$$
f=\frac{\left[\log \left(\frac{\mathrm{Re}^{0.56}}{3.196}\right)\right]^{-2}}{10.563} \rightarrow B=\log \left(\frac{\operatorname{Re}^{0.56}}{3.196}\right)
$$

Then Equation (70) is transformed to:

$$
f=\frac{B^{-2}}{10.563}
$$

Substituting Equation (71) into Equation (64)

$$
\begin{aligned}
& \left.N u=\frac{\operatorname{Re} \operatorname{Pr}}{10.563 B^{2} \cdot\left(8+\sqrt{1290.3 \cdot 10.563 \cdot B^{2}} \cdot\left(\operatorname{Pr}^{2 / 3}-1\right)\right.}\right) \\
& \cdot\left(1+\left(\frac{d}{l}\right)^{2 / 3}\right) \cdot\left(\frac{\mu_{F}}{\mu_{P}}\right)^{N}
\end{aligned}
$$

or

$$
\begin{aligned}
& N u=\frac{\operatorname{Re} \operatorname{Pr}}{84.5 B^{2}+116.74 B \cdot\left(\operatorname{Pr}^{2 / 3}-1\right)} \\
& \cdot\left(1+\left(\frac{d}{l}\right)^{2 / 3}\right) \cdot\left(\frac{\mu_{F}}{\mu_{P}}\right)^{N}
\end{aligned}
$$

Equation (73) can be written as [15]:

$$
\begin{aligned}
& N u=\frac{\operatorname{Re} \operatorname{Pr}}{A \cdot B^{2}-C \cdot B \cdot\left(1-\operatorname{Pr}^{2 / 3}\right)} . \\
& \cdot\left(1+\left(\frac{d}{l}\right)^{2 / 3}\right) \cdot\left(\frac{\mu_{F}}{\mu_{P}}\right)^{N}
\end{aligned}
$$

$$
\text { In Equation (74), } A=84.5 \text { and } C=116.74
$$

\section{EXPERIMENTAL VALIDATION OF THE PROPOSED MODEL}

Equation (74) was developed for turbulent flow in singlephase inside pipes. For the transitional zone, in this work, the authors prefer the adjustments obtained with the Gnielinsky's correction, predetermining it as a functional logarithmic of base 10 .

$$
\operatorname{Re} \approx\left(\operatorname{Re}-10^{D}\right)
$$

Applying the Brezhneztov's method, can be obtained the coefficient $D$ as one polynomial curve of second order, dependent of the functional $\log (D)$.

$$
D=-0.027 \cdot[\log (\operatorname{Re})]^{2}+0.2 \log (\operatorname{Re})+2.63
$$

Figure 1 shows the correlation between the Equation (76) and the experimental data [17]. For transitional zone, constants $A$ and $C$ in Equation (74) are determined through adjustment of experimental data. This correlation is showed in the figures 2 and 3 respectively.

For the turbulent flow regime, the constant $D$ is deleted, while the constants $A$ and $C$ in Equation (74) are determined through adjustment of experimental data [22]. This correlation is showed in the figures 4 and 5 respectively. Table 1 provides a detailed description of the new proposal model for transition and turbulent flow regime.

The proposal model covers a greater range of validity. To show its effectiveness, a correlation is made of the values 
obtained from the use of Equation (74) and the experimental data available [22-23], dividing the range of applicability into seven subintervals of validity and then the average error rate is determined. The results obtained are determined by determining the percent of average error. The results obtained are summarized in Tables 4 and 5.

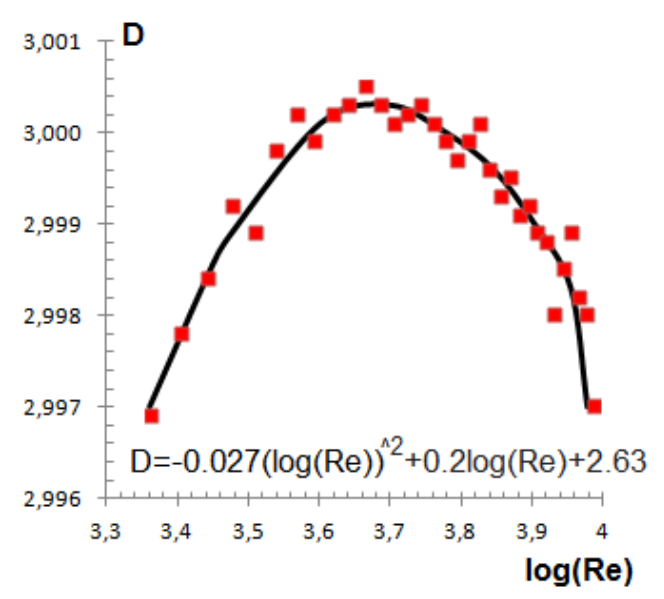

Figure 1. Comparison of experimental data with the Equation (76)

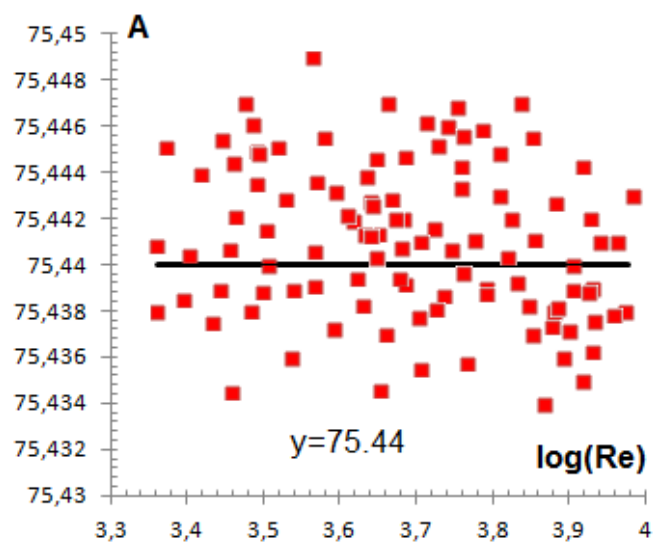

Figure 2. Determination of the constant $A$ for the Equation (74) in transition zone

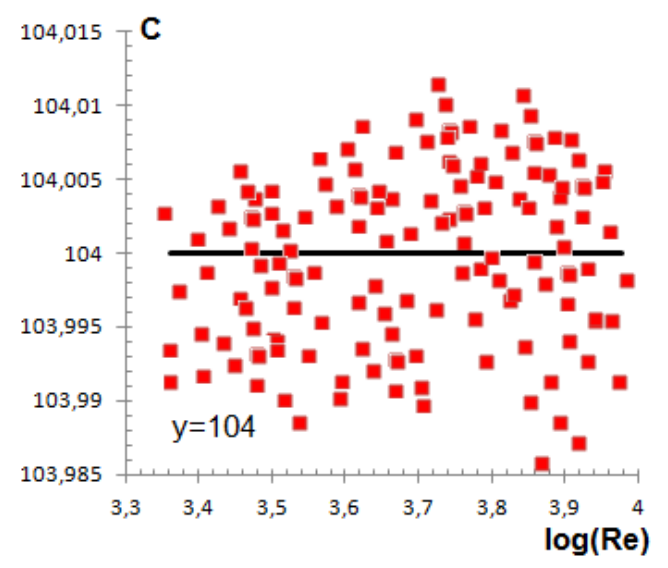

Figure 3. Determination of the constant $C$ for the Equation (74) in the transition zone

In the table 4 , for the validity range $2.4 \cdot 10^{3} \leq R e<10^{4}$ and $0.65<\operatorname{Pr} \leq 4.71 \cdot 10^{4}$, the proposal model correlates with an average error of $13.91 \%$, in $80.32 \%$ of the available experimental data, then, the obtained adjustment is considered excellent, very similar to those obtained by using the Gnielinsky Equation, which should be clarified that it cannot be used for $\operatorname{Pr}>2000$. It is also observed that for values of $\operatorname{Pr}$ $<200$, the average error obtained is $6.96 \%$ for $90.42 \%$ of the available data, which brings it numerically to the $5 \%$ reported by Gnielinsky.

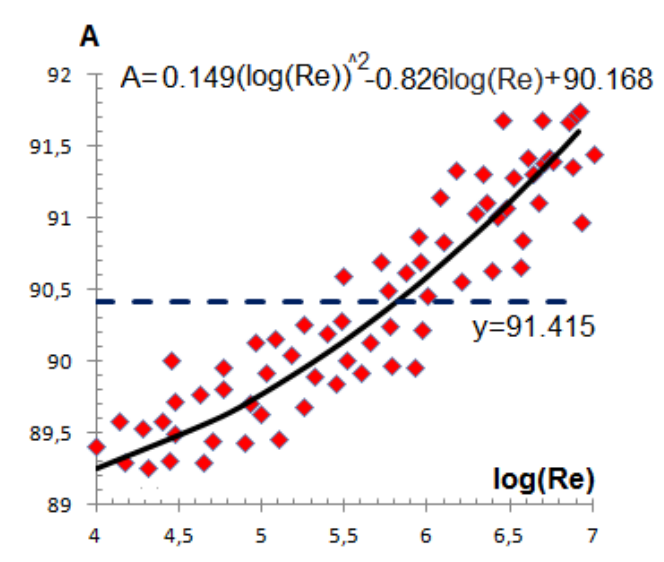

Figure 4. Determination of the constant $A$ for the Equation (74) in turbulent flow regime

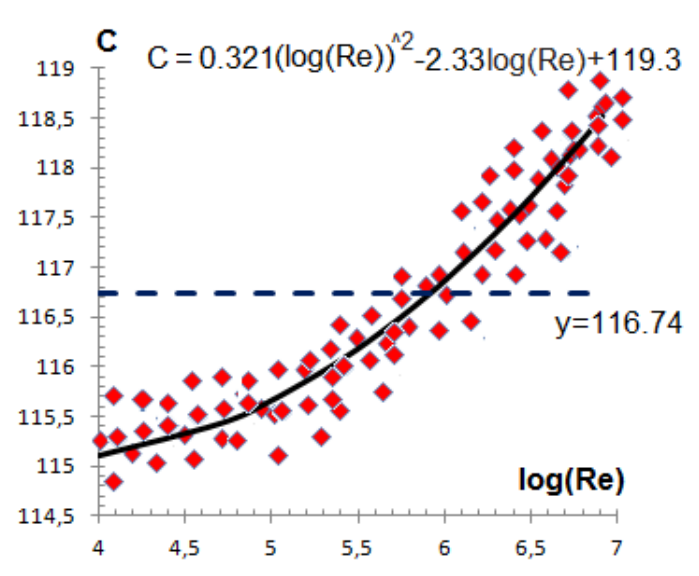

Figure 5. Determination of the constant $C$ for the Equation (74) in turbulent flow regime

Table 1. Description of the new proposal model for transition and turbulent flow regime

\begin{tabular}{c|c}
\hline & $N u=\frac{\left(\mathrm{Re}-10^{D}\right) \operatorname{Pr}}{A \cdot B^{2}-C \cdot B \cdot\left(1-\operatorname{Pr}^{2 / 3}\right)}$ \\
Equation (74) & $\cdot\left(1+\left(\frac{d}{l}\right)^{2 / 3}\right) \cdot\left(\frac{\mu_{F}}{\mu_{P}}\right)^{N}$ \\
\hline Transition zone & $2.3 \cdot 10^{3}<R e<1 \cdot 10^{4}$ \\
\hline$A$ & 75.44 \\
\hline$C$ & 104 \\
\hline$D$ & $-0.027 \cdot[\log (\mathrm{Re})]^{2}+0.2 \log (\mathrm{Re})+2.63$ \\
\hline Turbulent zone & $1 \cdot 10^{4}<R e$ \\
\hline$A$ & 91.415 \\
\hline$C$ & 116.74 \\
\hline$D$ & 0 \\
\hline
\end{tabular}

In the Table 5 for $10^{4} \leq R e \leq 8.2 \cdot 10^{6}$ and $0.65<\operatorname{Pr} \leq$ $4.71 \cdot 10^{4}$, the Equation (74) correlates with an average error of $13.96 \%$, in the $80.94 \%$ of the available experimental data, 
so the adjustment obtained is considered to be excellent, very similar to those obtained by using the Equations of Petukhov and Gnielinsky, which should be clarified that it cannot be used for $\operatorname{Pr}>2000$. It is also observed that for values of $\operatorname{Pr}<200$, the average error obtained is $7.12 \%$ for $88.35 \%$ of the available data, which brings it numerically to the $5 \%$ reported by Petukhov and Gnielinsky.

Table 2 provides a detailed summary of the range that shows a satisfactory fit with the correlation proposed in the present work.

Table 2. Summary of the validity range for the Equation (74)

\begin{tabular}{c|c}
\hline Parameter & Range \\
\hline \multirow{3}{*}{ Fluids } & $\begin{array}{c}\text { Water, Air, Helium, Hydrogen, Nitrogen, Carbon } \\
\text { Dioxide, Transformer oil, Glycerin, MC Oil, MK } \\
\text { Oil, Butyl alcohol, Methanol, Ethanol, Ethylene } \\
\text { glycol, Kerosene, Acetic Acid, Acetaldehyde, } \\
\text { Butanol, Aniline, Carbon Disulfide, Ciclohexane, } \\
\text { Ethyl ether, Ethylamine, Oil olive, Toluene, } \\
\text { Turpentine, Propylene, Pentane, Benzene, Gasoline, } \\
\text { Isobutene, Engine oil. Decane and Dodecane }\end{array}$ \\
\hline$P r$ & 0.65 to $4.71 \cdot 10^{4}$ \\
\hline$R e$ & $2.4 \cdot 10^{3}$ to $8.2 \cdot 10^{6}$ \\
\hline$\mu_{F} / \mu_{P}$ & $0.006 \leq \mu_{F} / \mu_{P} \leq 177$ \\
\hline$l / d$ & $2 \leq l / d \leq 420$ \\
\hline
\end{tabular}

In this work, the experimental data used in the validation of the developed model were extracted of the critical review available in the reference [22], which provides one large data base of experimental data compiled on heat transfer calculation during fluid flow in single-phase inside tubes. Table 3 provides the available experimental data used in this paper.

In Tables 4 and 5 can be appreciated that the Equation (74), is as accurate as the Equations of Petukhov and Gnielisky, allowing a wider range of application, while the results obtained are very similar. In the acknowledged literature was not found antecedent of a similar model with a wide range of validity. Therefore, the proposed model constitutes one contribution to the state of the art, on heat transfer calculation during fluid flow in single-phase inside pipes.
Table 4. Correlation adjustments with the experimental data for the first range of values available for Equation (74)

\begin{tabular}{|c|c|c|}
\hline \multicolumn{3}{|c|}{$2.4 \cdot 10^{3} \leq \operatorname{Re}<10^{4}$} \\
\hline $0.006<\frac{\mu_{F}}{\mu_{P}} \leq 12.42$ & $0.65<\operatorname{Pr} \leq 10^{2}$ & $\begin{array}{c}\text { error }<6.18 \% \\
91.32 \% \text { data }\end{array}$ \\
\hline $0.006<\frac{\mu_{F}}{\mu_{P}} \leq 18.35$ & $0.65<\operatorname{Pr} \leq 2 \cdot 10^{2}$ & $\begin{array}{c}\text { error }<6.96 \% \\
90.42 \% \text { data }\end{array}$ \\
\hline $0.006<\frac{\mu_{F}}{\mu_{P}} \leq 22.2$ & $0.65<\operatorname{Pr} \leq 2 \cdot 10^{3}$ & $\begin{array}{c}\text { error }<8.74 \% \\
89.14 \% \text { data }\end{array}$ \\
\hline $0.006<\frac{\mu_{F}}{\mu_{P}} \leq 34.16$ & $0.65<\operatorname{Pr} \leq 8.1 \cdot 10^{3}$ & $\begin{array}{c}\text { error }<9.96 \% \\
88.05 \% \text { data }\end{array}$ \\
\hline $0.006<\frac{\mu_{F}}{\mu_{P}} \leq 62.2$ & $0.65<\operatorname{Pr} \leq 1.2 \cdot 10^{4}$ & $\begin{array}{c}\text { error }<10.74 \% \\
86.42 \% \text { data }\end{array}$ \\
\hline $0.006<\frac{\mu_{F}}{\mu_{P}} \leq 105$ & $0.65<\operatorname{Pr} \leq 2.24 \cdot 10^{4}$ & $\begin{array}{c}\text { error }<12.18 \% \\
83.18 \% \text { data }\end{array}$ \\
\hline $0.006<\frac{\mu_{F}}{\mu_{P}} \leq 177$ & $0.65<\operatorname{Pr} \leq 4.71 \cdot 10^{4}$ & $\begin{array}{c}\text { error }<13.91 \% \\
80.32 \% \text { data }\end{array}$ \\
\hline
\end{tabular}

Table 5. Correlations with experimental data for the second range of values available for Equation (74)

\begin{tabular}{|c|c|c|}
\hline \multicolumn{3}{|c|}{$10^{4} \leq \operatorname{Re} \leq 8.2 \cdot 10^{6}$} \\
\hline $0.006<\frac{\mu_{F}}{\mu_{P}} \leq 12.42$ & $0.65<\operatorname{Pr} \leq 10^{2}$ & $\begin{array}{c}\text { error }<6.24 \% \\
89.36 \% \text { data }\end{array}$ \\
\hline $0.006<\frac{\mu_{F}}{\mu_{P}} \leq 18.35$ & $0.65<\operatorname{Pr} \leq 2 \cdot 10^{2}$ & $\begin{array}{c}\text { error }<7.12 \% \\
88.35 \% \text { data }\end{array}$ \\
\hline $0.006<\frac{\mu_{F}}{\mu_{P}} \leq 22.2$ & $0.65<\operatorname{Pr} \leq 2 \cdot 10^{3}$ & $\begin{array}{c}\text { error }<8.31 \% \\
87.12 \% \text { data }\end{array}$ \\
\hline $0.006<\frac{\mu_{F}}{\mu_{P}} \leq 34.16$ & $0.65<\operatorname{Pr} \leq 8.1 \cdot 10^{3}$ & $\begin{array}{c}\text { error }<10.17 \% \\
86.31 \% \text { data }\end{array}$ \\
\hline $0.006<\frac{\mu_{F}}{\mu_{P}} \leq 62.2$ & $0.65<\operatorname{Pr} \leq 1.2 \cdot 10^{4}$ & $\begin{array}{c}\text { error }<11.23 \% \\
84.02 \% \text { data }\end{array}$ \\
\hline $0.006<\frac{\mu_{F}}{\mu_{P}} \leq 105$ & $0.65<\operatorname{Pr} \leq 2.24 \cdot 10^{4}$ & $\begin{array}{c}\text { error }<13.37 \% \\
82.72 \% \text { data }\end{array}$ \\
\hline $0.006<\frac{\mu_{F}}{\mu_{P}} \leq 177$ & $0.65<\operatorname{Pr} \leq 4.71 \cdot 10^{4}$ & $\begin{array}{c}\text { error }<13.96 \% \\
80.94 \% \text { data }\end{array}$ \\
\hline
\end{tabular}

Figure 6 shows the correlation between the proposed model and the experimental data reported by various authors.

Table 3. Experimental data used in the validation of the Equation (74)

\begin{tabular}{|c|c|c|c|c|c|c|c|}
\hline Source & Number of data & Fluid & $1 / \mathrm{d}$ & $R e \cdot 10^{3}$ & $\operatorname{Pr}$ & $\mu_{F} / \mu_{P}$ & $\begin{array}{c}\text { Deviatio } \\
\mathrm{n} \text { percent }\end{array}$ \\
\hline I'lin (1951) & 188 & Air & $\begin{array}{c}41 \\
162 \\
\end{array}$ & $\begin{array}{c}7 \\
6600 \\
\end{array}$ & $\begin{array}{c}0.68 \\
0.7\end{array}$ & $\begin{array}{l}0.65 \\
1.65\end{array}$ & $\begin{array}{l}5.3 \\
3.5 \\
\end{array}$ \\
\hline Volkov (1966) & 218 & Air & $\begin{array}{c}48 \\
370\end{array}$ & $\begin{array}{l}12.5 \\
3700 \\
\end{array}$ & $\begin{array}{c}0.68 \\
0.7\end{array}$ & $\begin{array}{l}0.65 \\
1.65 \\
\end{array}$ & $\begin{array}{l}6,2 \\
1,5 \\
\end{array}$ \\
\hline Petukhov (1963) & 140 & Air & $\begin{array}{c}39 \\
100\end{array}$ & $\begin{array}{c}15 \\
5800\end{array}$ & $\begin{array}{c}0.68 \\
0.7 \\
\end{array}$ & $\begin{array}{l}0.65 \\
1.65 \\
\end{array}$ & $\begin{array}{l}4,4 \\
2,1 \\
\end{array}$ \\
\hline \multirow{3}{*}{ Sukomiel (1962) } & 44 & Helium & $\begin{array}{l}20 \\
50\end{array}$ & $\begin{array}{c}9 \\
40\end{array}$ & $\begin{array}{l}0.71 \\
0.72\end{array}$ & $\begin{array}{c}0.22 \\
4.5\end{array}$ & $\begin{array}{r}7,1 \\
-2,3\end{array}$ \\
\hline & 67 & $\begin{array}{c}\text { Isobutene (2- } \\
\text { Methylpropane) }\end{array}$ & $\begin{array}{c}2 \\
60 \\
\end{array}$ & $\begin{array}{l}3200 \\
7200 \\
\end{array}$ & $\begin{array}{l}0,73 \\
0,75 \\
\end{array}$ & $\begin{array}{l}0.68 \\
1.46 \\
\end{array}$ & $\begin{array}{c}9,7 \\
-6,4 \\
\end{array}$ \\
\hline & 148 & Water & $\begin{array}{c}6 \\
64 \\
\end{array}$ & $\begin{array}{c}12 \\
540\end{array}$ & $\begin{array}{l}0.9 \\
9.4\end{array}$ & $\begin{array}{l}0.19 \\
0.77\end{array}$ & $\begin{array}{c}8,2 \\
-7,9 \\
\end{array}$ \\
\hline Eckert (1964) & 93 & Turpentine & $\begin{array}{l}10 \\
90\end{array}$ & $\begin{array}{c}13 \\
110 \\
\end{array}$ & $\begin{array}{l}14.3 \\
29.8 \\
\end{array}$ & $\begin{array}{l}0.41 \\
2.43 \\
\end{array}$ & $\begin{array}{r}11,6 \\
-14,7 \\
\end{array}$ \\
\hline \multirow{2}{*}{ Sabersky (1963) } & 33 & Water & $\begin{array}{l}48 \\
61\end{array}$ & $\begin{array}{l}120 \\
160\end{array}$ & $\begin{array}{l}1.2 \\
5.9\end{array}$ & $\begin{array}{l}0.24 \\
0.86\end{array}$ & $\begin{array}{c}10,2 \\
1,1\end{array}$ \\
\hline & 52 & Pentane & $\begin{array}{l}46 \\
88 \\
\end{array}$ & $\begin{array}{l}150 \\
620\end{array}$ & $\begin{array}{l}4.5 \\
7.1 \\
\end{array}$ & $\begin{array}{l}0.47 \\
2.08 \\
\end{array}$ & $\begin{array}{l}13,1 \\
-9,6 \\
\end{array}$ \\
\hline Yakolev (1960) & 39 & Water & $\begin{array}{l}70 \\
90 \\
\end{array}$ & $\begin{array}{c}19 \\
140\end{array}$ & $\begin{array}{c}2 \\
12 \\
\end{array}$ & $\begin{array}{l}0.21 \\
1.15 \\
\end{array}$ & $\begin{array}{l}12,6 \\
-3,9 \\
\end{array}$ \\
\hline
\end{tabular}




\begin{tabular}{|c|c|c|c|c|c|c|c|}
\hline Sabersky (1965) & 62 & Water & $\begin{array}{c}60 \\
180\end{array}$ & $\begin{array}{c}35 \\
120\end{array}$ & $\begin{array}{c}1 \\
9.44\end{array}$ & $\begin{array}{l}0.13 \\
7.15\end{array}$ & $\begin{array}{c}13,1 \\
9,9\end{array}$ \\
\hline \multirow{4}{*}{$\begin{array}{l}\text { Sterman-Petukhov } \\
\text { (1970) }\end{array}$} & 41 & Transformer oil & $\begin{array}{c}89 \\
125\end{array}$ & $\begin{array}{c}3.4 \\
13.8\end{array}$ & $\begin{array}{c}34.9 \\
1530\end{array}$ & $\begin{array}{c}0.01 \\
115.2\end{array}$ & $\begin{array}{c}12,7 \\
-10,3\end{array}$ \\
\hline & 29 & Glycerin & $\begin{array}{c}89 \\
125\end{array}$ & $\begin{array}{l}2.5 \\
9.1\end{array}$ & $\begin{array}{c}1630 \\
22650\end{array}$ & $\begin{array}{c}0.018 \\
55,4\end{array}$ & $\begin{array}{c}9,2 \\
-5,4\end{array}$ \\
\hline & 49 & MC Oil & $\begin{array}{c}66 \\
165 \\
\end{array}$ & $\begin{array}{c}5 \\
10.4 \\
\end{array}$ & $\begin{array}{c}120 \\
9800 \\
\end{array}$ & $\begin{array}{l}0,007 \\
133,3 \\
\end{array}$ & $\begin{array}{r}14,8 \\
-17,1 \\
\end{array}$ \\
\hline & 27 & MK Oil & $\begin{array}{c}80 \\
145 \\
\end{array}$ & \begin{tabular}{|l}
5.4 \\
8.7 \\
\end{tabular} & $\begin{array}{c}590 \\
39000 \\
\end{array}$ & $\begin{array}{c}0.011 \\
88.7 \\
\end{array}$ & $\begin{array}{c}15.8 \\
-12.6 \\
\end{array}$ \\
\hline Kreith (1947) & 20 & Butyl Alcohol & 38 & $\begin{array}{l}42 \\
78\end{array}$ & $\begin{array}{l}23 \\
30\end{array}$ & $\begin{array}{l}0.08 \\
0.45\end{array}$ & $\begin{array}{c}15,3 \\
-12,2 \\
\end{array}$ \\
\hline Ykolev et al. (1965) & 50 & Benzene & $\begin{array}{c}60 \\
110\end{array}$ & $\begin{array}{c}2.6 \\
21.1\end{array}$ & $\begin{array}{c}3.2 \\
5\end{array}$ & $\begin{array}{l}0.31 \\
3.17\end{array}$ & $\begin{array}{c}8,8 \\
-4,8\end{array}$ \\
\hline \multirow{2}{*}{ Humbble (1993) } & 113 & Gasoline & $\begin{array}{c}60 \\
190\end{array}$ & $\begin{array}{c}70 \\
6900\end{array}$ & $\begin{array}{c}5.5 \\
15.1\end{array}$ & $\begin{array}{c}0.22 \\
4.4 \\
\end{array}$ & $\begin{array}{l}10,4 \\
-6,1 \\
\end{array}$ \\
\hline & 181 & Hydrogen & $\begin{array}{l}43 \\
67 \\
\end{array}$ & $\begin{array}{c}12 \\
8200\end{array}$ & $\begin{array}{l}0.65 \\
0.73\end{array}$ & $\begin{array}{l}0.48 \\
3.28 \\
\end{array}$ & $\begin{array}{l}-2.4 \\
-8.8 \\
\end{array}$ \\
\hline Kirilov (1967) & 125 & Nitrogen & $\begin{array}{l}100 \\
138\end{array}$ & $\begin{array}{c}6 \\
8100 \\
\end{array}$ & $\begin{array}{l}0.68 \\
0.75\end{array}$ & $\begin{array}{c}0.15 \\
6.5 \\
\end{array}$ & $\begin{array}{l}9,8 \\
1,9\end{array}$ \\
\hline Efimok (1969) & 19 & Carbon Dioxide & $\begin{array}{c}77 \\
206\end{array}$ & $\begin{array}{c}14 \\
660\end{array}$ & $\begin{array}{l}0.66 \\
0.81\end{array}$ & $\begin{array}{l}0.3 \\
3.3\end{array}$ & $\begin{array}{l}7,4 \\
0,7\end{array}$ \\
\hline Yan-Lin (1999) & 91 & Water & $\begin{array}{c}2 \\
420 \\
\end{array}$ & $\begin{array}{c}4 \\
250 \\
\end{array}$ & $\begin{array}{c}0.94 \\
11 \\
\end{array}$ & $\begin{array}{l}0.19 \\
0.96 \\
\end{array}$ & $\begin{array}{c}9,9 \\
-11.5 \\
\end{array}$ \\
\hline Tarashmova (2001) & 23 & Water & $\begin{array}{c}20 \\
450 \\
\end{array}$ & $\begin{array}{c}400 \\
2500\end{array}$ & $\begin{array}{c}0.94 \\
11 \\
\end{array}$ & $\begin{array}{l}0.19 \\
0.96 \\
\end{array}$ & $\begin{array}{l}13,6 \\
-8,9 \\
\end{array}$ \\
\hline Karkalala (2012) & 44 & Water & $\begin{array}{l}18 \\
51\end{array}$ & $\begin{array}{l}1200 \\
2800\end{array}$ & $\begin{array}{l}1.2 \\
5.9\end{array}$ & $\begin{array}{l}0.24 \\
0.96 \\
\end{array}$ & $\begin{array}{l}5.3 \\
4.5 \\
\end{array}$ \\
\hline Jung et al. (2008) & 71 & Transformer oil & $\begin{array}{c}19 \\
150 \\
\end{array}$ & $\begin{array}{l}2.8 \\
8.1 \\
\end{array}$ & $\begin{array}{l}34.9 \\
4800 \\
\end{array}$ & $\begin{array}{l}1.2 \\
28 \\
\end{array}$ & $\begin{array}{l}16,2 \\
-7,5 \\
\end{array}$ \\
\hline Carpenter (1957) & 66 & Methanol & $\begin{array}{c}45 \\
120 \\
\end{array}$ & $\begin{array}{c}2.9 \\
1112.1 \\
\end{array}$ & $\begin{array}{l}2.2 \\
7.7 \\
\end{array}$ & $\begin{array}{l}0.1 \\
9.9 \\
\end{array}$ & $\begin{array}{l}4,4 \\
2,1 \\
\end{array}$ \\
\hline & 112 & Kerosene & $\begin{array}{c}30 \\
280 \\
\end{array}$ & $\begin{array}{c}6.4 \\
52.8 \\
\end{array}$ & $\begin{array}{c}1.35 \\
2.9 \\
\end{array}$ & $\begin{array}{c}0.38 \\
2.6 \\
\end{array}$ & $\begin{array}{r}7,1 \\
-2,3 \\
\end{array}$ \\
\hline & 47 & Acetic acid & $\begin{array}{c}55 \\
135 \\
\end{array}$ & $\begin{array}{c}3.1 \\
987.8 \\
\end{array}$ & $\begin{array}{c}8.5 \\
14.2 \\
\end{array}$ & $\begin{array}{l}0.8 \\
1.2 \\
\end{array}$ & $\begin{array}{c}4,7 \\
-3,7 \\
\end{array}$ \\
\hline & 38 & Acetaldehyde & $\begin{array}{c}65 \\
120 \\
\end{array}$ & $\begin{array}{c}3.9 \\
52.4 \\
\end{array}$ & $\begin{array}{c}2.85 \\
4.4 \\
\end{array}$ & $\begin{array}{l}0.4 \\
2.1 \\
\end{array}$ & $\begin{array}{c}8,2 \\
-7,9 \\
\end{array}$ \\
\hline Vasserman (1962) & 141 & Butanol & $\begin{array}{c}40 \\
160 \\
\end{array}$ & $\begin{array}{c}5.4 \\
822.6 \\
\end{array}$ & $\begin{array}{c}22.5 \\
3860 \\
\end{array}$ & $\begin{array}{l}0.04 \\
24.6 \\
\end{array}$ & $\begin{array}{r}11,6 \\
-16,7 \\
\end{array}$ \\
\hline & 187 & Aniline & $\begin{array}{c}50 \\
280 \\
\end{array}$ & $\begin{array}{c}4.4 \\
1024.2 \\
\end{array}$ & $\begin{array}{l}11.5 \\
111 \\
\end{array}$ & $\begin{array}{c}0.08 \\
12.35 \\
\end{array}$ & $\begin{array}{c}9,7 \\
-3.5 \\
\end{array}$ \\
\hline & 37 & Carbon Disulfide & $\begin{array}{c}48 \\
125 \\
\end{array}$ & $\begin{array}{l}13.8 \\
76.9 \\
\end{array}$ & $\begin{array}{l}2.3 \\
3.2 \\
\end{array}$ & $\begin{array}{l}0.59 \\
1.68 \\
\end{array}$ & $\begin{array}{l}10,2 \\
-1,1 \\
\end{array}$ \\
\hline & 23 & Ciclohexane & $\begin{array}{c}85 \\
220 \\
\end{array}$ & $\begin{array}{l}36.1 \\
89.4 \\
\end{array}$ & $\begin{array}{c}11 \\
19.9 \\
\end{array}$ & $\begin{array}{l}0.5 \\
1.9 \\
\end{array}$ & $\begin{array}{r}2.3 \\
-1.7 \\
\end{array}$ \\
\hline & 113 & Ethanol & $\begin{array}{c}80 \\
125 \\
\end{array}$ & $\begin{array}{c}21.4 \\
1513.8 \\
\end{array}$ & $\begin{array}{c}6.9 \\
68.4 \\
\end{array}$ & $\begin{array}{c}0.049 \\
20.5 \\
\end{array}$ & $\begin{array}{l}5.2 \\
7.4 \\
\end{array}$ \\
\hline & 71 & Ethyl ether & $\begin{array}{c}70 \\
135 \\
\end{array}$ & $\begin{array}{c}580 \\
2560 \\
\end{array}$ & $\begin{array}{l}3.5 \\
7.3 \\
\end{array}$ & $\begin{array}{l}0.3 \\
3.6 \\
\end{array}$ & $\begin{array}{l}4.2 \\
8.1 \\
\end{array}$ \\
\hline & 17 & Ethylamine & $\begin{array}{c}80 \\
100 \\
\end{array}$ & $\begin{array}{l}12.1 \\
17.8 \\
\end{array}$ & $\begin{array}{l}5.1 \\
8.3 \\
\end{array}$ & $\begin{array}{c}0.55 \\
1.8 \\
\end{array}$ & $\begin{array}{c}3.2 \\
-6.1 \\
\end{array}$ \\
\hline Sherwood (1967) & 21 & Propylene & $\begin{array}{c}60 \\
120 \\
\end{array}$ & $\begin{array}{l}125 \\
284 \\
\end{array}$ & $\begin{array}{l}2.8 \\
3.2 \\
\end{array}$ & $\begin{array}{l}0.27 \\
3.66 \\
\end{array}$ & $\begin{array}{c}9.1 \\
-4.8 \\
\end{array}$ \\
\hline & 36 & Dodecane & $\begin{array}{c}70 \\
150\end{array}$ & $\begin{array}{l}72 \\
96 \\
\end{array}$ & $\begin{array}{l}10.7 \\
28.2\end{array}$ & $\begin{array}{l}0.4 \\
3.3 \\
\end{array}$ & $\begin{array}{c}11.1 \\
-12.4 \\
\end{array}$ \\
\hline & 40 & Decane & $\begin{array}{c}65 \\
135 \\
\end{array}$ & $\begin{array}{c}16 \\
47.2 \\
\end{array}$ & \begin{tabular}{|c|}
6.8 \\
17.1 \\
\end{tabular} & $\begin{array}{c}0.25 \\
4.1 \\
\end{array}$ & $\begin{array}{c}2.3 \\
-7.8 \\
\end{array}$ \\
\hline & 53 & Ethylene glycol & $\begin{array}{c}90 \\
165 \\
\end{array}$ & $\begin{array}{c}6.3 \\
12.1 \\
\end{array}$ & $\begin{array}{c}69 \\
510 \\
\end{array}$ & $\begin{array}{c}0.12 \\
8.1 \\
\end{array}$ & $\begin{array}{c}7.1 \\
-9.3 \\
\end{array}$ \\
\hline Gordon (1937) & 11 & Oil olive & $\begin{array}{c}85 \\
120\end{array}$ & $\begin{array}{l}2.7 \\
7.6\end{array}$ & $\begin{array}{l}700 \\
810\end{array}$ & $\begin{array}{l}0.3 \\
2.9 \\
\end{array}$ & $\begin{array}{c}9.1 \\
-11.4\end{array}$ \\
\hline Gordon (1939) & 13 & Toluene & $\begin{array}{c}70 \\
150 \\
\end{array}$ & $\begin{array}{c}3.9 \\
27.2 \\
\end{array}$ & $\begin{array}{c}4.7 \\
21.1 \\
\end{array}$ & $\begin{array}{l}0.1 \\
7.8 \\
\end{array}$ & $\begin{array}{l}11.6 \\
-9.4 \\
\end{array}$ \\
\hline GMC (2012) & 103 & Engine Oil & $\begin{array}{c}30 \\
180\end{array}$ & $\begin{array}{l}2.4 \\
7.2 \\
\end{array}$ & $\begin{array}{c}84 \\
47100 \\
\end{array}$ & $\begin{array}{c}0.006 \\
177\end{array}$ & $\begin{array}{c}14.1 \\
-19.4 \\
\end{array}$ \\
\hline For all sources above & 3096 & & $\begin{array}{c}2.0 \\
450 \\
\end{array}$ & $\begin{array}{c}2.4 \\
8200 \\
\end{array}$ & $\begin{array}{c}0.65 \\
47100 \\
\end{array}$ & $\begin{array}{c}0.006 \\
177 \\
\end{array}$ & $\begin{array}{c}16.2 \\
-19.4 \\
\end{array}$ \\
\hline
\end{tabular}




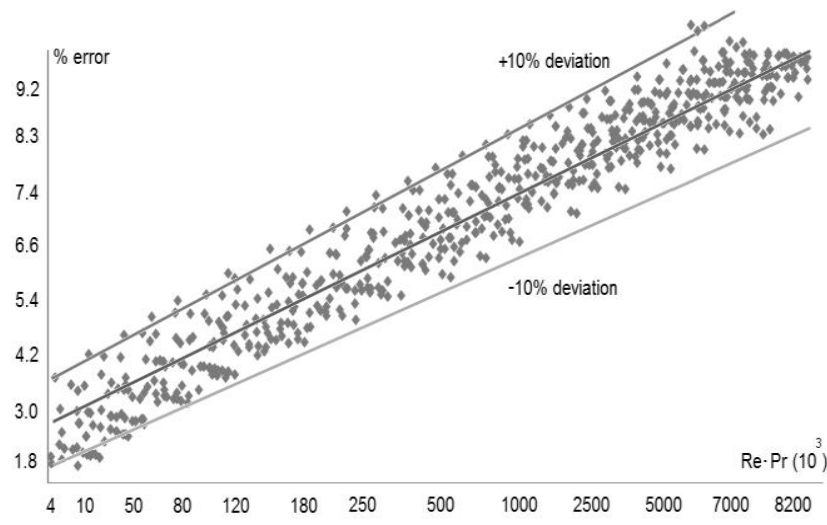

Figure 6. Application of the model to experimental data reported by several authors

\section{CONCLUSIONS}

A new model has been obtained for the determination of the heat transfer coefficient in transition and turbulent regime, on a fluid flow in single phase inside straight tubes. The model obtained has a greater range of applicability, covering almost twice the permissible values for the models that were taken as reference, establishing its domain in a range not covered by any model established and known in the literature, for this reason recommends its use in the calculation of the mean coefficients of heat transfer by convection for straight tubes with turbulent flow and transition.

For validity range $2.4 \cdot 10^{3} \leq R e<10^{4}$ and $0.65<\operatorname{Pr} \leq$ $4.71 \cdot 10^{4}$, the proposal model correlates with an average error of $13.91 \%$, in $80.32 \%$ of the available experimental data. For $2.4 \cdot 10^{3} \leq R e<10^{4}$ and $\operatorname{Pr}<200$, the average error obtained is $6.96 \%$ for $90.42 \%$ of the available data. For validity range $10^{4} \leq R e \leq 8.2 \cdot 10^{6}$ and $0.65<\operatorname{Pr} \leq 4.71 \cdot 10^{4}$, the proposal model correlates with an average error of $13.96 \%$, in $80.94 \%$ of the available experimental data. For $10^{4} \leq R e \leq$ $8.2 \cdot 10^{6}$ and $\operatorname{Pr}<200$, the mean error obtained is $7.12 \%$ for $88.35 \%$ of the available data.

\section{ACKNOWLEDGMENT}

The Doctoral program of the Universidad Central "Marta Abreu" de Las Villas, Santa Clara, Cuba, is gratefully acknowledged.

\section{REFERENCES}

[1] Dirker J, Van der Vyver H. (2004). Convection heat transfer in concentric annuli. Experimental Heat Transfer 17(1):

19-29. http://doi.org/10.1080/08916150490246528

[2] Liu D, Zheng Y, Moore A, Ferdows M. (2017). Spectral element simulations of three dimensional convective heat transfer. International Journal of Heat and Mass Transfer 111: 1023-1038. http://doi.org/10.1016/j.ijheatmasstransfer.2017.04.066

[3] Will JB, Kruyt NP, Venner CH. (2017). An experimental study of forced convective heat transfer. International Journal of Heat and Mass Transfer 109: 1059-1067. http://doi.org/10.1016/j.ijheatmasstransfer.2017.02.028
[4] Cttani L, Bozzoli F, Raineri S. (2017). Experimental study of the transitional flow regime in coiled tubes by the estimation of local convective heat transfer coefficient. International Journal of Heat and Mass Transfer 112: 825-836. http://doi.org/10.1016/j.ijheatmasstransfer.2017.04.066

[5] Gschnaidtner T, Schatte GA, Kohlhepp A, Wang Y, Wieland C, Spliethoff H. (2018). A new assessment method for the evaluation of supercritical heat transfer correlations, particularly with regard to the "multiple/no solutions" problem. Thermal Science and Engineering Progress 7: 267-278. https://doi.org/10.1016/j.tsep.2018.07.006

[6] Muhammad-Ali H, Briggs A. (2015). A semi-empirical model for free-convection condensation on horizontal pin-fin tubes. International Journal of Heat and Mass Transfer 81 : 157-166. http://dx.doi.org10.1016j.ijheatmasstransfer.2014.10.00 8

[7] Zhang W, Du X, Yang L, Yang Y. (2016). Research on performance of finned tube bundles of indirect air-cooled. Mathematical Modelling of Engineering Problems 3(1): 47-51. http://doi.org/10.18280/mmep.030108

[8] Costa-Magazoni F, Cabezas-Gómez L, Fariñas-Alvariño P, Sáiz-Jabardo JM. (2019). Closed form relationships of temperature effectiveness of cross-flow heat exchangers. Thermal Science and Engineering Progress 9: 110-120. https://doi.org/10.1016/j.tsep.2018.11.005

[9] Camaraza-Medina Y, Rubio-Gonzales AM, CruzFonticiella OM, García-Morales OF. (2017). Analysis of pressure influence over heat transfer coefficient on air cooled condenser. Journal Européen des Systems Automatisés 50(3): 213-226. http://dx.doi.org/10.3166/jesa.50.213-226

[10] Elshafei EAM, Awad MM, El-Negiry E, Ali AG. (2010). Heat transfer and pressure drop in corrugated channels. Energy 35(1): 101-110. http://doi.org/10.1016/j.energy.2009.08.031

[11] Camaraza-Medina Y, Cruz-Fonticiella OM, GarcíaMorales OF. (2018). Predicción de la presión de salida de una turbina acoplada a un condensador de vapor refrigerado por aire. Centro Azúcar 45(1): 50-61.

[12] Dattas AK, Yanase S, Kochi T, Shatat MME. (2017). Laminar forced convective heat transfer in helical pipe flow. International Journal of Thermal Sciences 120: 4149. http://doi.org/10.1016/j.ijthermalsci.2017.05.026

[13] Liu F, Cai Y, Wang L, Zhao J. (2018). Effect of nanoparticle shape on laminar forced convective heat transfer in curved ducts using two-model. International Journal of Heat and Mass Transfer 116: 825-836. http://doi.org/10.1016/j.ijthermalsci.2017.08.097

[14] Camaraza-Medina Y, Rubio-Gonzales AM, CruzFonticiella OM, García-Morales OF, Vizcón-Toledo R, Quiza-Sardiñas R. (2018). Simplified analysis of heat transfer through a finned tube bundle in air cooled condenser--second assessment. Mathematical Modelling of Engineering Problems 5(4): 365-372. https://doi.org/10.18280/mmep.050413

[15] Medina YC, Khandy NH, Fonticiella OMC, Morales OFG. (2017). Abstract of heat transfer coefficient modelation in single-phase systems inside pipes. Mathematical Modelling of Engineering Problems 4(3): 126-131. https://doi.org/10.18280/mmep.040303

[16] Medina YC, Fonticiella OMC, Morales OFG. (2017). 
Design and modelation of piping systems by means of use friction factor in the transition turbulent zone. Mathematical Modelling of Engineering Problems 4(4): 162-167. https://doi.org /10.18280/mmep.040404

[17] Medina YC, Khandy NH, Carlson KM, Fonticiella OMC, Morales OFG. (2018). Mathematical modeling of twophase media heat transfer coefficient in air cooled condenser system. International Journal of Heat and Technology 36(1): https://doi.org/10.18280/ijht.360142

[18] Camaraza-Medina Y, Hernández-Guerrero A, LuvianoOrtiz JL, Mortensen-Carlson K, Cruz-Fonticiella OM, García-Morales OF. (2019). New model for heat transfer calculation during film condensation inside pipes. International Journal of Heat and Mass Transfer 128: 344-353.

https://doi.org/10.1016/j.ijheatmasstransfer.2018.09.012

[19] Mondal S, Field RW. (2018). Theoretical analysis of the viscosity correction factor for heat transfer in pipe flow. Chemical Engineering Science 187: 27-32. https://doi.org/10.1016/j.ces.2018.04.047

[20] Camaraza-Medina Y, Khandy NH, Carlson KM, CruzFonticiella OM, García-Morales OF, Reyes-Cabrera D. (2018). Evaluation of condensation heat transfer in aircooled condenser by dominant flow criteria. Mathematical Modelling of Engineering Problems 5(2): 76-82. https://doi.org /10.18280/mmep.050204

[21] Binu TV, Jayanti S. (2018). Heat transfer enhancement due to internal circulation within a rising fluid drop. Thermal Science and Engineering Progress 8: 385-396. https://doi.org/10.1016/j.tsep.2018.09.009

[22] Camaraza Y. (2017). Introducción a la termo transferencia, Editorial Universitaria, La Habana.

[23] Camaraza-Medina Y, Cruz-Fonticiella OM, GarciaMorales OF. (2019). New model for heat transfer calculation during fluid flow in single phase inside pipes. Thermal Science and Engineering Progress. https://doi.org/10.1016/j.tsep.2019.03.014

\section{NOMENCLATURE}

a Thermal diffusivity, $\mathrm{m}^{2} \cdot \mathrm{s}^{-1}$

A Constant, defined in Equation (74)

$B$ Constant, defined in Equation (74)

$C$ Constant, defined in Equation (74)

$C_{p} \quad$ Fluid specific heat, $\mathrm{J} \cdot \mathrm{kg}^{-1} \cdot \mathrm{K}^{-1}$

$C_{W}$ Drag coefficient d Equivalent inner tube diameter, $\mathrm{m}$

$D$ Constant, defined in Equation (74)

$f \quad$ Darcy friction factor

$l \quad$ Length of the tube, $m$

$L \quad$ Initial section of hydrodynamic compensation, $\mathrm{m}$

$L_{C} \quad$ Mixture length of the energy in the thickness $\delta_{3}, \mathrm{~m}$

$L_{M} \quad$ Mixture length of the thickness $\delta_{2}, \mathrm{~m}$

$N$ Exponent of the Petukhov correction in Equation (63)

$\mathrm{Nu}$ Nusselt number

Pr Prandtl number for single-phase

$q^{*} \quad$ Total heat flux, $\mathrm{kg} \cdot \mathrm{m}^{-2} \cdot \mathrm{s}^{-3}$

$q_{0}^{*} \quad$ Heat flux on the boundary layer surface, $\mathrm{kg} \cdot \mathrm{m}^{-2} \cdot \mathrm{s}^{-3}$

$q_{\text {cond }}$ Conductive component of the total heat flux, $\mathrm{kg} \cdot \mathrm{m}^{-2} \cdot \mathrm{s}^{-}$

$q_{\text {turb }}$ Turbulent component of the total heat flux, $\mathrm{kg} \cdot \mathrm{m}^{-2} \cdot \mathrm{s}^{-3}$

$R e$ Reynolds number for single-phase

St Stanton number

$T_{F} \quad$ Mean fluid temperature, ${ }^{\circ} \mathrm{C}$

$T_{I} \quad$ Instantaneous temperature used in Equation (5), ${ }^{\circ} \mathrm{C}$

$T_{F}^{*} \quad$ Temperature fluctuation used in Equation (5), ${ }^{\circ} \mathrm{C}$

$T_{P} \quad$ Wall temperature, ${ }^{\circ} \mathrm{C}$

$V_{1} \quad$ Velocity at the edge of the viscous layer, $\mathrm{m} \cdot \mathrm{s}^{-1}$

$V_{M} \quad$ Mean fluid velocity, $\mathrm{m} \cdot \mathrm{s}^{-1}$

$V_{X}^{*} \quad$ Fluctuation of the $V_{X}^{M}, \mathrm{~m} \cdot \mathrm{s}^{-1}$

$V_{Y}^{*} \quad$ Fluctuation of the $V_{Y}^{M}, \mathrm{~m} \cdot \mathrm{s}^{-1}$

$V_{X}^{M}$ Instantaneous velocity in the coordinate axis $x$ used in Equation (2), $\mathrm{m} \cdot \mathrm{s}^{-1}$

$V_{Y}^{M}$ Instantaneous velocity in the coordinate axis $y$ used in Equation (3), $\mathrm{m} \cdot \mathrm{s}^{-1}$

\section{Greek symbols}

$\alpha \quad$ Heat transfer coefficient in single-phase, $\mathrm{kg} \cdot \mathrm{m}^{-1} \cdot \mathrm{K}^{-1} \cdot \mathrm{s}^{-1}$

$\varepsilon_{C} \quad$ Heat turbulent diffusivity, $\mathrm{m}^{2} \cdot \mathrm{s}^{-1}$

$\varepsilon_{M} \quad$ Momentum turbulent diffusivity, $\mathrm{m}^{2} \cdot \mathrm{s}^{-1}$

$\mu_{F} \quad$ Fluid dynamic viscosity at $T_{F}, \mathrm{~kg} \cdot \mathrm{m}^{-1} \cdot \mathrm{s}^{-1}$

$\mu_{P} \quad$ Fluid dynamic viscosity at $T_{P}, \mathrm{~kg} \cdot \mathrm{m}^{-1} \cdot \mathrm{s}^{-1}$

$\rho \quad$ Fluid density, $\mathrm{kg} \cdot \mathrm{m}^{-3}$

$\lambda \quad$ Fluid thermal conductivity, $\mathrm{W} \cdot \mathrm{m}^{-1} \cdot \mathrm{K}^{-1}$

$v \quad$ Liquid kinematic viscosity, $\mathrm{m}^{2} \cdot \mathrm{s}^{-1}$

$\delta_{2} \quad$ Film thickness of the momentum in boundary layer, $\mathrm{m}$

$\delta_{3} \quad$ Film thickness of the thermal boundary layer, $\mathrm{m}$

$\tau \quad$ Shear stress in the turbulent boundary layer, $\mathrm{kg} \cdot \mathrm{m} \cdot \mathrm{s}^{-2}$

$\tau_{0} \quad$ Shear stress on the surface of the turbulent boundary layer, $\mathrm{kg} \cdot \mathrm{m} \cdot \mathrm{s}^{-2}$

$\tau_{\text {Visc }}$ Stress of the viscous forces, $\mathrm{kg} \cdot \mathrm{m} \cdot \mathrm{s}^{-2}$

$\tau_{\text {Turb }}$ Stress of the turbulent strain, $\mathrm{kg} \cdot \mathrm{m} \cdot \mathrm{s}^{-2}$

$\Delta P \quad$ Pressure drop, $\mathrm{m}$ 